\title{
Genome-wide transcriptional response of an avian pathogenic Escherichia coli (APEC) pst mutant Sébastien Crépin ${ }^{1,2}$, Martin G Lamarche ${ }^{1,2}$, Philippe Garneau¹, Julie Séguin², Julie Proulx ${ }^{2}$, Charles M Dozois ${ }^{2}$ and Josée Harel*1
}

\author{
Address: ${ }^{1}$ Groupe de Recherche sur les Maladies Infectieuses du Porc (GREMIP), Université de Montréal, Faculté de médecine vétérinaire, C. P \\ 5000, Saint-Hyacinthe, Québec, J2S 7C6, Canada and 2Institut National de la Recherche Scientifique, INRS-Institut Armand-Frappier, Laval, \\ Québec, Canada \\ Email: Sébastien Crépin - sebastien.crepin@iaf.inrs.ca; Martin G Lamarche - martin.lamarche@iaf.inrs.ca; \\ Philippe Garneau - philippe.garneau@umontreal.ca; Julie Séguin - julie.seguin2@iaf.inrs.ca; Julie Proulx - julie.proulx@iaf.inrs.ca; \\ Charles M Dozois - charles.dozois@iaf.inrs.ca; Josée Harel* - josee.harel@umontreal.ca \\ * Corresponding author
}

Published: 28 November 2008

BMC Genomics 2008, 9:568 doi:10.1/86/147|-2164-9-568
Received: 29 May 2008

Accepted: 28 November 2008

This article is available from: http://www.biomedcentral.com//47/-2/64/9/568

(c) 2008 Crépin et al; licensee BioMed Central Ltd.

This is an Open Access article distributed under the terms of the Creative Commons Attribution License (http://creativecommons.org/licenses/by/2.0), which permits unrestricted use, distribution, and reproduction in any medium, provided the original work is properly cited.

\begin{abstract}
Background: Avian pathogenic E. coli (APEC) are associated with extraintestinal diseases in poultry. The pstSCAB-phoU operon belongs to the Pho regulon and encodes the phosphate specific transport (Pst) system. A functional Pst system is required for full virulence in APEC and other bacteria and contributes to resistance of APEC to serum, to cationic antimicrobial peptides and acid shock. The global mechanisms contributing to the attenuation and decreased resistance of the APEC pst mutant to environmental stresses have not been investigated at the transcriptional level. To determine the global effect of a pst mutation on gene expression, we compared the transcriptomes of APEC strain $\chi 7122$ and its isogenic pst mutant (K3) grown in phosphate-rich medium.
\end{abstract}

Results: Overall, 470 genes were differentially expressed by at least I.5-fold. Interestingly, the pst mutant not only induced systems involved in phosphate acquisition and metabolism, despite phosphate availability, but also modulated stress response mechanisms. Indeed, transcriptional changes in genes associated with the general stress responses, including the oxidative stress response were among the major differences observed. Accordingly, the K 3 strain was less resistant to reactive oxygen species (ROS) than the wild-type strain. In addition, the pst mutant demonstrated reduced expression of genes involved in lipopolysaccharide modifications and coding for cell surface components such as type I and F9 fimbriae. Phenotypic tests also established that the pst mutant was impaired in its capacity to produce type I fimbriae, as demonstrated by western blotting and agglutination of yeast cells, when compared to wild-type APEC strain $\chi 7 \mid 22$.

Conclusion: Overall, our data elucidated the effects of a pst mutation on the transcriptional response, and further support the role of the Pho regulon as part of a complex network contributing to phosphate homeostasis, adaptive stress responses, and $E$. coli virulence. 


\section{Background}

In Escherichia coli and many other bacterial species, the Pho regulon is activated when cells face phosphate limitation, whereas its expression is inhibited in excess of phosphate. The two-component system (TCS) PhoR/PhoB responds to environmental phosphate concentration variations and has been shown to control expression of at least 47 genes [1,2]. PhoR is an inner membrane sensor protein that responds to periplasmic orthophosphate $\left(\mathrm{P}_{\mathrm{i}}\right)$ concentrations and $\mathrm{PhoB}$ is the response regulator of the Pho regulon. PhoR is activated when the $\mathrm{P}_{\mathrm{i}}$ concentration is below $4 \mu \mathrm{M}$. Under $\mathrm{P}_{\mathrm{i}}$-limited conditions, PhosphoPhoB binds to specific DNA sequences known as PhoBoxes, located within Pho-dependent promoter regions to either induce or repress gene transcription. The pstSCABphoU operon encodes the Pst system and belongs to the Pho regulon. The Pst system encodes an ATP-binding cassette (ABC) transporter involved in the transport of $\mathrm{P}_{\mathrm{i}}$. Importantly, mutations in the Pst system result in constitutive expression of the Pho regulon, regardless of environmental phosphate availability, and affect virulence of many pathogenic bacteria [1].

Extraintestinal pathogenic Escherichia coli (ExPEC) strains are associated with various diseases, including urinary tract infections (UTIs), newborn meningitis (NBM), abdominal sepsis and septicemia [3]. In poultry, APEC strains are a frequent cause of extraintestinal infections, collectively called colibacillosis. In addition, E. coli O78 strains can also cause diseases in hosts other than poultry, such as swine, sheep, and humans [4].

We have previously shown that inactivation of the pst operon in porcine and avian ExPEC strains resulted in constitutive expression of the Pho regulon and rendered the strains avirulent $[4,5]$. Moreover, it was reported that the phoB gene of the avian pathogenic E. coli (APEC) $\chi 7122$ strain is expressed during infection [6]. In accordance, in ExPEC strains, other PhoB regulated genes were shown to be expressed in vivo $[7,8]$. A number of reports have described an association between the Pst system, the Pho regulon and bacterial virulence [1]. Although inactivation of pst genes has been shown to affect the virulence of a number of bacterial pathogens, the mechanisms underlying this attenuation have not been elucidated.

Microarray studies have been conducted to understand how E. coli K-12 responds to growth in phosphate-rich or phosphate-limited conditions in phoB mutant strains $[9,10]$. Moreover, proteome profiles of cells grown under phosphate-rich or phosphate-limited conditions revealed that the overall phosphate response of E. coli may comprise up to 400 genes [11]. However, these studies investigated non-pathogenic E. coli K-12 grown in phosphatelimiting conditions. To understand global responses resulting from a mutation in the Pst system, which constitutively activates the Pho regulon, and its relationship with APEC virulence, the transcriptional profile of the APEC $\chi 7122$ strain was compared with its isogenic Pst mutant (K3) using the Affymetrix GeneChip ${ }^{\circledast}$ E. coli Genome 2.0 Array. The Pho regulon is clearly not a simple regulatory circuit for controlling phosphate homeostasis; it is part of a complex network important for both bacterial virulence and the global stress response. Regulatory changes incurred due to inactivation of the Pst system resulted in modulation of genes involved in cell surface modifications, production of fimbrial adhesins, and protection against environmental stresses in the APEC mutant. These regulatory changes are likely to contribute to its reduced virulence and increased sensitivity to environmental stresses which may be encountered during host infection.

\section{Methods \\ Bacterial strains, media and growth conditions}

The APEC strain $\chi 7122$, the $\chi 7122 \Delta p s t C A B$ mutant (K3), and the complemented $\chi 7122 \Delta$ pstCAB mutant (CK3) were previously described $[4,12,13]$. The $\chi 7122 \Delta$ fim strain $\chi 7279$ was generated by allelic exchange using suicide vector pDM915 as described by Marc et al. [12]. E. coli strains were grown at $37^{\circ} \mathrm{C}$ in Luria-Bertani (LB) medium. Antibiotics or supplements were used at the following final concentration, when required: $40 \mu \mathrm{g} / \mathrm{ml}$ for nalidixic acid (Nal), $50 \mu \mathrm{g} / \mathrm{ml}$ for kanamycin (Kan), $12.5 \mu \mathrm{g} / \mathrm{ml}$ for chloramphenicol $(\mathrm{Cm})$ and $40 \mu \mathrm{g} / \mathrm{ml}$ for 5-bromo-4chloro-3-indolylphosphate di-sodium (XP).

\section{Alkaline phosphatase assay}

Alkaline phosphatase activity was measured as described previously with slight modifications [4]. Briefly, cells grown under different conditions were adjusted to an optical density of 1.0 at $600 \mathrm{~nm}\left(\mathrm{OD}_{600}\right)$, and $4 \mu \mathrm{g} / \mathrm{ml}$ of p-nitrophenyl phosphate (Sigma) was added to cells permeabilized by $50 \mu \mathrm{l}$ of $0.1 \%$ SDS and $50 \mu \mathrm{l}$ of chloroform. Color development was monitored at $420 \mathrm{~nm}$ and alkaline phosphatase activity was expressed in Miller units $(\mathrm{MU})$, calculated as follows: $1000 \times\left[\mathrm{OD}_{420}-(1.75 \times\right.$ $\left.\left.\left.\mathrm{OD}_{550}\right)\right] / T(\mathrm{~min}) \times V(\mathrm{ml}) \times \mathrm{OD}_{600}\right]$.

\section{RNA isolation}

RNA extractions were performed using four biological replicates of cultures of strains $\chi 7122$ and K3. Briefly, overnight cultures grown at $37^{\circ} \mathrm{C}$ in LB broth were diluted 100 -fold into $5 \mathrm{ml}$ of $\mathrm{LB}$ broth and were allowed to grow to mid-log phase $\left(\mathrm{OD}_{600} 0.6\right)$. RNA samples were extracted with the RiboPure ${ }^{\mathrm{TM}}$-Bacteria Kit (Ambion, Austin, TX), according to the manufacturer's recommendations, with the exception that DNAse I treatment was performed twice. RNA concentration and purity were measured using the Nanodrop ND-1000 spectrophotom- 
eter (NanoDrop Technologies, Wilmington, DE) and the 2100 Bioanalyzer (Agilent Technologies, Santa Clara, CA). Quantitative RT-PCR (qRT-PCR) was performed on each RNA sample using a Smart Cycler (Cepheid, Sunnyvale, CA) to detect any DNA contamination. For this purpose, primers targeting the $r p o D$ gene were used. RNAs were stored at $-80^{\circ} \mathrm{C}$ for future use.

\section{cDNA synthesis and biotinylation}

Ten $\mu \mathrm{g}$ of RNA dissolved in $20 \mu \mathrm{l}$ of RNAse-, DNAse- and pyrogen-free water (Sigma) were supplemented with $2 \mu \mathrm{l}$ of the GeneChip ${ }^{\circledast}$ Eukaryotic Poly-A RNA Control Kit (Affymetrix, Santa Clara, CA) and converted into cDNA using SuperScript II and random hexanucleotide primers (Invitrogen, Carlsbad, CA), according to the manufacturer's instructions. Following cDNA synthesis, $2 \mu \mathrm{l}$ of 1 $\mathrm{mg} / \mathrm{ml}$ of RNAse A (Sigma) were added to the reaction mix and samples were incubated at $37^{\circ} \mathrm{C}$ for $30 \mathrm{~min}$ to degrade remaining RNA. cDNAs were purified using Microcon YM-30 centrifugal filters (Milipore, Billerica, $\mathrm{MA}$ ). Concentration and purity were measured using the Nanodrop ND-1000 spectrophotometer. A range between 3 to $7 \mu \mathrm{g}$ of cDNAs was fragmented using DNAse I (Ambion, Austin, TX), at concentration of $0.5 \mathrm{U} / \mu \mathrm{g}$ of cDNA, and by incubating at $37^{\circ} \mathrm{C}$ for $10 \mathrm{~min}$. Fragmentation was stopped by heating the reaction mixture at $98^{\circ} \mathrm{C}$ for $10 \mathrm{~min}$. Fragmented cDNAs were $3^{\prime}$ biotinylated using GeneChip DNA Labelling Reagent (Affymetrix, Santa Clara, CA) at $7.5 \mathrm{mM}$ and $60 \mathrm{U}$ of Terminal Deoxynucleotidyl Transferase (Promega, Madison, WI) at $37^{\circ} \mathrm{C}$ for 60 min. The reaction was stopped by adding $2 \mu \mathrm{l}$ of $0.5 \mathrm{M}$ EDTA (Sigma). A gel-shift assay on 14\% polyacrylamide gel using ImmunoPure NeutrAvidin (Pierce Chemical, Rockford, IL) was monitored to determine biotin incorporation.

\section{DNA microarray hybridization and analysis}

The cDNAs were hybridized onto the Affymetrix GeneChip ${ }^{\circledast}$ E.coli Genome 2.0 Array (Affymetrix, Santa Clara, $\mathrm{CA})$ as recommended by the manufacturer http:// www.affymetrix.com. Hybridizations were performed at the Génome Québec Innovation Centre (McGill University, Montréal, Canada). Data were processed using the robust multiarray average algorithm (RMA) for normalization, background correction and expression value calculation [14]. Expression levels obtained from four independent biological replicates were compared using FlexArray 1.1 software [15]. Robustness of the data was further enhanced by the EB (Wright and Simon) algorithm and p-value calculation. Since the RMA algorithm diminished the false positive rate and compressed the fold change, a 1.5-fold change cut-off value was used for determination of the differentially expressed genes [16]. Functional classification was done according to the TIGR's Comprehensive Microbial Resource (CMR) [17]. Patho- gen-associated ORFs were classified as such, since they represent sequences corresponding to one or more of the three pathogenic E. coli genomes (EDL933, Sakai and CFT073), but which are absent from the genome of E. coli K-12 strain MG1655.

\section{Quantitative RT-PCR}

The QIAGEN QuantiTect ${ }^{\circledast}$ SYBR $^{\circledR}$ Green RT-PCR kit was used for qRT-PCR according to the manufacturer's instructions. Primer pairs were designed using the PrimerQuest software from Integrated DNA Technologies http:// www.idtdna.com/Scitools/Applications/Primerquest/ to yield PCR products varying between 80 to $200 \mathrm{bp}$. The tus gene was used as a housekeeping control. Each qRT-PCR run was done in triplicate and for each reaction, the calculated threshold cycle $(\mathrm{Ct})$ was normalized to the $\mathrm{Ct}$ of the tus gene amplified from the corresponding sample. The fold-change was calculated using the $2^{-\Delta \Delta \mathrm{Ct}}$ method [18]. Sequences of primers used for qRT-PCR analysis are available in additional file 1.

\section{In silico search for Pho box(es)}

We used the DNA Pattern search program available on the Colibri $^{\circledR}$ website http://genolist.pasteur.fr/Colibri/. The search was performed by using the pattern $\mathrm{n}[\mathrm{at}] ! \mathrm{c} ! \mathrm{c} ! \mathrm{g}$ [at]!a!g!g!gn!g!g [tg] [ta] [ac]a [tc]nnn!g, where "n" represents any nucleotide, characters between square brackets " []" means an ambiguity and "!" before a character indicates the negation of this position. This pattern was designed based on different $E$. coli Pho box sequences presented by Blanco et al. [19]. We performed the DNA pattern search on the E. coli K-12 MG1655 whole genome, with no mismatch allowed, narrowing our search to the 200 bp upstream of predicted start codons. We also used the gene list containing predicted PhoB binding sites using the Pho box weight matrix elaborated by Yuan et al. [20]. Searches were performed against the E. coli MG1655, EDL933, Sakai, and CFT073 genomes which are represented on the Affymetrix GeneChip ${ }^{\circledR}$ E. coli Genome 2.0 array.

\section{Sensitivity of E. coli strains to reactive oxygen intermediate (ROI)-generating agents}

Sensitivity to oxidative stress generating agents was determined by an agar overlay diffusion method on LB plates (1.5\% agar) as described by Sabri et al. [21]. Briefly, overnight cultures grown in LB broth were adjusted to an $\mathrm{OD}_{600}$ of 0.5 . Then, $100 \mu \mathrm{l}$ of each culture were suspended in molten top agar $(0.5 \%$ agar $)$ and poured over the agar plates. Filter paper disks ( $6 \mathrm{~mm}$ diameter; Beckton Dickinson) were added to the surface of the solidified overlays and $10 \mu \mathrm{l}$ of hydrogen peroxide (30\%), plumbagin (53 $\mathrm{mM})$, phenazine methosulfate (PMS) $(15 \mathrm{mM})$ or phenazine ethosulfate (PES) $(15 \mathrm{mM})$ were spotted onto the disks. The plates were then incubated overnight at $37^{\circ} \mathrm{C}$ 
and following growth, the diameters of inhibition zones were measured.

\section{Yeast Cell Aggregation Assay}

The yeast aggregation assay was derived from a microhemagglutination assay in 96-well round-bottom plates [13]. Briefly, cultures were grown to mid-log phase $\left(\mathrm{OD}_{600} 0.6\right)$ in $\mathrm{LB}$ broth at $37^{\circ} \mathrm{C}$ with shaking $(180 \mathrm{rpm})$ (conditions which were used for transcriptional analyses) or for $48 \mathrm{~h}$ without shaking at $37^{\circ} \mathrm{C}$ to enhance expression of type 1 fimbriae. Bacterial cells were centrifuged, and pellets were suspended in phosphate buffered saline (PBS, pH 7.4) to an initial suspension of approximately 2 $\times 10^{11}$ cells $/ \mathrm{ml}$. Samples were then serially diluted twofold in microtiter wells, and equal volumes of a 3\% commercial yeast suspension were added to each of the wells. After 30 min of incubation on ice, yeast aggregation was monitored visually, and the agglutination titer was recorded as the most diluted bacterial sample giving a positive aggregation reaction. The $\Delta$ fim type 1 fimbriae mutant strain $\chi 7279$ was used as a negative control.

\section{Preparation of fimbrial extracts and Western blotting}

Following growth of cultures with agitation at $37^{\circ} \mathrm{C}$ in $\mathrm{LB}$ to mid-exponential growth phase $\left(\mathrm{OD}_{600} 0.6\right)$, fimbrial extracts were prepared and Western blotting was performed as described previously [22]. Briefly, fimbrial extracts were separated by sodium dodecyl sulfate (SDS)$15 \%$ polyacrylamide gel electrophoresis in minigels as previously described by Laemmli [23]. Proteins were transferred to nitrocellulose membranes (Bio-Rad) using a Mini Trans-Blot electrophoretic cell (Bio-Rad) for 60 min at $100 \mathrm{~V}$. The membrane was blocked with StartingBlock (Pierce) supplemented with $0.05 \%$ Tween 20 (Pierce). Incubations with primary (1:5000) and secondary (1:25 000) antibodies were carried out for $1 \mathrm{~h}$ at room temperature. SuperSignal West Pico chemiluminescent substrate (Pierce) was used for detection. Primary antibodies, raised against type 1 fimbriae from $E$. coli strain $\mathrm{B}_{\mathrm{AM}}$, were used, and react specifically with type 1 fimbriae from different APEC strains [24].

\section{Electron microscopy}

Cells for electron microscopy were grown as described above for microarray experiments. A glow-discharged Formvar-coated copper grid was placed onto a drop of bacterial culture for $1 \mathrm{~min}$ to allow the cells to adsorb. The excess of liquid was then removed using a filter paper, just before a drop of $1 \%$ phosphotungstic acid (negative stain) was placed onto the grid. Samples were left to air dry and viewed using a Phillips EM300 transmission electron microscope.

\section{Microarray accession numbers}

Microarray data are available at the National Center for Biotechnology Information Gene Expression Omnibus database http://www.ncbi.nlm.nih.gov/geo under accession number GSE9178.

\section{Results and discussion \\ Microarray design to identify differentially expressed genes in the APEC pst mutant}

To assess the effects of a pst mutation as well as Pho regulon activation on APEC strain $\chi 7122$, a transcriptional profiling approach was used. Strain $\chi 7122$ and its isogenic pst mutant (K3) were grown in a phosphate-rich (LB) medium. In this medium, strains $\chi 7122$ and K3 grew well, and they showed similar growth curves (data not shown). The alkaline phosphatase activity of PhoA is commonly used to evaluate the activation state of the Pho regulon [25]. The Pho regulon induction reaches its maximal rate at mid-log phase of growth in strain $\mathrm{K} 3$ as determined by PhoA activity (200 MU), whereas it was repressed in the wild-type parent strain $\chi 7122$ (3 MU). Thus, in the K3 strain, the Pho regulon is highly activated even during growth in phosphate-rich LB medium.

The Affymetrix GeneChip E. coli genome 2.0 Array contains oligonucleotides corresponding to four E. coli genomes (E. coli K-12 MG1655, E. coli enterohemorrhagic EDL933 and Sakai and extraintestinal E. coli (ExPEC) CFT073). Avian pathogenic Escherichia coli (APEC), a frequent cause of extraintestinal infections in poultry, are categorized as ExPEC. Although the genome sequence of the $\chi 7122$ APEC strain is not yet available, it is now known that the APEC O1:K1 strain genome shares $90 \%$ similarity with the CFT073 ORFs [26]. This suggests that probes on the GeneChip could represent at least in part the genome of $\chi 7122$. In addition, to determine the representative gene targets on the array that were present in strain $\chi 7122$, hybridization of $\chi 7122$ genomic DNA revealed that, among the 20,366 ORFs represented on the DNA array, 5751 were specific to the $\chi 7122$ genome. The non-K-12 ORFs were considered as pathogen-associated ORFs.

\section{Significant transcriptional changes in the K3 pst mutant}

The transcriptomic study identified 470 genes that were differentially expressed by at least 1.5 -fold in the pst mutant strain K3 when compared to the APEC strain $\chi 7122$, with a p-value of $\leq 0.05$ and an estimated false discovery rate (FDR) of $2.71 \%$. Globally, 254 genes were upand 216 were down-regulated. Specific subsets of differentially expressed genes of known physiological relevance or putative function are discussed below and presented in Tables 1 and 2. A complete list of the differentially expressed genes is available online (see additional files 2 and 3). These tables contain genes that are discussed below and represent significant change at the transcriptional level occurring in Pho regulon activation. The known genes of the Pho regulon were induced varying from 145- to 2-fold. Besides those, the gadW gene showed 
Table I: Up-regulated genes in K3 strain

\begin{tabular}{|c|c|c|c|}
\hline Functional class and gene name $e^{a, b, c, d, e, f, g}$ & Operonc,d,e,f,h & Known or predicted function & Fold change \\
\hline \multicolumn{4}{|l|}{ Transport and binding protein } \\
\hline artl & $\operatorname{artPIQM}^{d}$ & Arginine-binding periplasmic protein I & 1.74 \\
\hline artjc & & Arginine-binding periplasmic protein 2 & 1.78 \\
\hline$f e o B$ & feoAcB & Ferrous iron transport protein & 2.19 \\
\hline$g \ln H^{c}$ & $g \ln H P Q^{d}$ & $\begin{array}{l}\text { Glutamine } A B C \text { transporter periplasmic-binding } \\
\text { protein }\end{array}$ & 1.57 \\
\hline$m d t E^{\mathrm{e}}$ & $m d t E F$ & Multidrug resistance efflux transporter & 1.64 \\
\hline$o p p A^{c}$ & орpABCDF & Periplasmic oligopeptide-binding protein & 2.66 \\
\hline$p h n C^{b, c}$ & phnCDEFGHIJKLMNOP & Phosphonates transport ATP-binding protein & $|45.8|$ \\
\hline phoE $E^{\mathrm{b}, \mathrm{c}}$ & & Outer membrane phosphoporin protein & 85.15 \\
\hline potE & speF-potE & Putrescine-ornithine antiporter & 2.56 \\
\hline$p s t S^{b, c}$ & pstSCAB-phoU & High-affinity phosphate-specific transport system & 60.97 \\
\hline $\operatorname{srl} A^{c}$ & srIAEBD-gutM-srIR`-gutQ & $\begin{array}{l}\text { PTS system, glucitol/sorbitol-specific IIC2 } \\
\text { component }\end{array}$ & 4.61 \\
\hline$u g p B^{b, c, d}$ & ugpBAEC $\mathrm{d} Q$ & $\begin{array}{l}\text { sn-glycerol 3-phosphate transport system } \\
\text { periplasmic binding protein }\end{array}$ & 40.00 \\
\hline yeaN & yeaNO & Putative amino acid/amine transport protein & 2.91 \\
\hline yhiDd,e & & $\begin{array}{l}\text { Predicted } \mathrm{Mg}(2+) \text { transport ATPase inner } \\
\text { membrane protein }\end{array}$ & 2.35 \\
\hline \multicolumn{4}{|l|}{ Energy metabolism } \\
\hline dhaK & dhaKLM & Dihydroxyacetone kinase & 1.85 \\
\hline $\operatorname{grx} B$ & & Glutaredoxin 2 & 1.85 \\
\hline hcp & hcp-hcr & Hydroxylamine reductase & 1.63 \\
\hline melA & melAB & Alpha-galactosidase & 3.24 \\
\hline $\operatorname{nag} B$ & nagBACD & Glucosamine-6-phosphate deaminase & 1.83 \\
\hline napH & napFDAGHBC-ccmABCDEFGH & Quinol dehydrogenase membrane component & 2.56 \\
\hline nrfa & nrfABCDEFG & $\begin{array}{l}\text { Cytochrome c552/nitrite reductase, formate- } \\
\text { dependent }\end{array}$ & 3.74 \\
\hline talAc,d & & Transaldolase & 1.57 \\
\hline $\operatorname{tre} A^{c, d}$ & & Periplasmic trehalase & 1.67 \\
\hline ulaB & ulaABcCDEF & L-ascorbate-specific enzyme IIB component of PTS & 2.46 \\
\hline ulaG & & Predicted L-ascorbate 6-phosphate lactonase & 2.04 \\
\hline \multicolumn{4}{|l|}{ Protein fate } \\
\hline$h d e A^{\mathrm{d}, \mathrm{e}}$ & hdeAB ${ }^{\mathrm{d}, \mathrm{e}}$ & Acid-resistance protein & 2.10 \\
\hline iraPc,d & & Anti-adaptor protein for $\delta$ stabilization & 4.42 \\
\hline \multicolumn{4}{|l|}{ Cellular processes } \\
\hline$a m n^{b, c}$ & & AMP nucleosidase & 6.08 \\
\hline$k a t E^{d}$ & & Catalase HPII/hydroperoxidase HPII(III) & 1.95 \\
\hline $\operatorname{sod} C^{f}$ & & Superoxide dismutase $(\mathrm{Cu}-\mathrm{Zn})$ & 1.75 \\
\hline$y c g V$ & & Predicted adhesin & 4.01 \\
\hline \multicolumn{4}{|l|}{ Transcription } \\
\hline chaB & chaBC & Cation transport regulator & 1.75 \\
\hline $\operatorname{gadE} \mathrm{e}$ & & DNA-binding transcriptional activator & 3.60 \\
\hline $\operatorname{gad} X^{\mathrm{d}, \mathrm{e}}$ & & DNA-binding transcriptional dual regulator & 2.15 \\
\hline $\operatorname{gadW} \mathrm{d}, \mathrm{e}$ & & DNA-binding transcriptional activator & 6.84 \\
\hline$i c i A^{b, c}$ & & Chromosome replication initiation inhibitor protein & 2.00 \\
\hline phoB b,c & phoBR & $\begin{array}{l}\text { DNA-binding response regulator in two-component } \\
\text { regulatory system with PhoR (or CreC) }\end{array}$ & 36.23 \\
\hline yhiFe & & Predicted transcriptional regulator & 1.66 \\
\hline \multicolumn{4}{|l|}{ Central intermediary metabolism } \\
\hline $\operatorname{gad} A c, \mathrm{~d}, \mathrm{e}$ & & Glutamate decarboxylase alpha & 2.57 \\
\hline $\operatorname{gadB} \mathrm{c}, \mathrm{d}, \mathrm{e}$ & $\operatorname{gad} B C$ & Glutamate decarboxylase beta & 4.91 \\
\hline phoA b,c & phoA-psiF & Alkaline phosphatase & 112.67 \\
\hline sufAe & SUfABCDSE & Iron-sulfur cluster assembly scaffold protein & 1.91 \\
\hline \multicolumn{4}{|l|}{ Cell enveloppe } \\
\hline yibD & & Putative glycosyl transferase & 45.95 \\
\hline \multicolumn{4}{|l|}{ Fatty acid and phospholipid metabolism } \\
\hline$c d h$ & & CDP-diacylglycerol phosphotidylhydrolase & 4.28 \\
\hline$h d h A^{d}$ & & 7-alpha-hydroxysteroid dehydrogenase & 1.52 \\
\hline
\end{tabular}


Table I: Up-regulated genes in $\mathbf{K 3}$ strain (Continued)

\begin{tabular}{|c|c|c|c|}
\hline c0754g & & Hypothetical protein & 2.12 \\
\hline c0778g & c0778-speF-potE & Hypothetical protein & 2.43 \\
\hline c0902 & & Hypothetical protein & 1.65 \\
\hline $\mathrm{cl} 013$ & & Hypothetical protein & 1.83 \\
\hline cl/53c,g & & Hypothetical protein & 2.35 \\
\hline cl435g & & Hypothetical protein & 2.26 \\
\hline c2837g & & Hypothetical protein & 1.53 \\
\hline c4/82 & & Hypothetical protein & 1.76 \\
\hline phoH $H^{b, c}$ & & $\begin{array}{l}\text { Conserved protein with nucleoside triphosphate } \\
\text { hydrolase domain }\end{array}$ & 5.95 \\
\hline$p s i E^{b, c}$ & & Phosphate-starvation-inducible protein & 1.84 \\
\hline$y t f K^{b}$ & & Hypothetical protein & 6.65 \\
\hline z0950g & & Unknown & 1.58 \\
\hline \multicolumn{4}{|c|}{ Biosynthesis of cofactors, prosthetic groups and carriers } \\
\hline iucDg & iucABCD-iutA & Lysine/ornithine N-monooxygenase & 1.76 \\
\hline \multicolumn{4}{|c|}{ Regulatory function } \\
\hline$d p s^{\mathrm{d}, \mathrm{f}}$ & & DNA protection during starvation conditions & 1.87 \\
\hline isrA & & Small antisense RNA & 1.64 \\
\hline sgrs & & Small antisense RNA & 1.98 \\
\hline rybA & & Small antisense RNA & 1.59 \\
\hline rygC & & Small antisense RNA & 1.50 \\
\hline$y d d V$ & yddV-dos & Predicted diguanylate cyclase & 1.80 \\
\hline
\end{tabular}

a The first up-regulated gene of the operon is shown, b Members of the Pho regulon c Indicates the presence of Pho box in the gene promoter, ${ }^{d}$ Genes belonging to RpoS regulon, e Genes involved in acid stress response, ${ }^{f}$ Genes involved in oxidative stress response, 8 Pathogen-associated ORF, ${ }^{\mathrm{h}}$ Genes in bold are up-regulated in $\mathrm{K} 3$ strain.

the highest induction (6.8-fold), whereas the greatest repression was observed for the $y h c N$ gene (-7.8-fold). Functional classification of the differentially expressed genes (Fig. 1) indicated predominant transcriptional changes among genes associated with cellular homeostasis and metabolism. Genes that were up-regulated included those encoding proteins of unknown function, transport and binding proteins, energy and central intermediary metabolism, and transcription (Table 1). Genes that were down-regulated also included the unknown function genes, as well as those involved with protein fate; protein synthesis; DNA metabolism; purine, pyrimidine, nucleoside and nucleotide pathways; and cell envelope proteins (Table 2). In addition, 5 small RNAs (sRNA) were differentially expressed. As expected, expression patterns of the genome-wide transcriptional response observed in the pst mutant in phosphate-rich medium shared similarities with transcriptomic analyses of non-pathogenic $E$. coli $\mathrm{K}-12$ during phosphate starvation $[9,10]$. However, in contrast to E. coli K-12 which demonstrated marked phosphate limitation by early stationary phase $\left(\mathrm{OD}_{600}\right.$ of 0.9$)$, the APEC pst mutant exhibited an early maximal induction of the Pho regulon following growth to mid-log phase $\left(\mathrm{OD}_{600} 0.6\right)$ in LB medium [10]. In addition, many genes associated with stress responses and metabolic functions were differentially expressed by the APEC pst mutant when compared to its wild-type parent.

In contrast to the many differentially expressed E. coli genes involved in general metabolic or transport functions, only a few confirmed virulence- or stress-response associated genes demonstrated significant transcriptional changes in the pst mutant. Of these, genes involved in acid and oxidative stress response were modulated. Furthermore, genes encoding type 1 and F9 fimbriae were down-regulated in strain K3. However, the majority of the pathogen-associated ORFs identified are of unknown function. Among the 470 differentially expressed genes, 18 were not found in E. coli K-12 strain MG1655 and were considered as pathogen-associated ORFs. Of these, 14 were specific to CFT073 and 4 to the EHEC (EDL933 and Sakai) genomes. Overall we identified 18 pathogen-associated ORFs that are influenced by constitutive expression of the Pho regulon. However, the functions encoded by these ORFs are currently unknown.

Modulation of the pathogen-associated ORFs (Table 1 and 2) could contribute to the reduced virulence of strain $\mathrm{K} 3$ observed by Lamarche et al. [4]. Interestingly, the virulence-associated gene systems sitABCD, iroBCDEN, iucA$B C D$-iutA, coding for metal transporters present in $\chi 7122$, that hybridized to the genomic array, were not differentially expressed in the attenuated pst mutant.

Blanco et al. showed that the C-terminal domain of PhoB interacts with a 22 bp region of dsDNA that consists of two direct repeats of $11 \mathrm{bp}$ [19]. Each 11 bp repeat has a conserved 7 bp region (consensus, CTGTCAT) followed by a less conserved 4 bp segment. By in silico analysis and by using the list of genes identified in E. coli genomes by Yuan et al., a number of genes with predicted Pho boxes not associated with $P_{i}$ metabolism were identified among 
Table 2: Down-regulated genes in K3 strain

\begin{tabular}{|c|c|c|c|}
\hline $\begin{array}{l}\text { Functional class and gene } \\
\text { name }^{a, b, c, d, e, f}\end{array}$ & Operon ${ }^{b, c, d, e, g}$ & Known or predicted function & Fold \\
\hline \multicolumn{4}{|c|}{ Transport and binding protein } \\
\hline $\operatorname{dct} A$ & & C4-dicarboxylate transport protein & -2.03 \\
\hline fadL & & Long-chain fatty acid transporter & -1.69 \\
\hline proV & proVWX & Glycine betaine transporter subunit & -2.30 \\
\hline \multicolumn{4}{|l|}{ Energy metabolism } \\
\hline fuclb & fucPIKUR & L-fucose isomerase & -1.59 \\
\hline$g \mid p D^{c}$ & & Aerobic glycerol-3-phosphate dehydrogenase & -3.56 \\
\hline$g l p E^{b}$ & glpEGR & Thiosulfate sulfurtransferase & -2.04 \\
\hline$g \mid p T$ & glpTQ & sn-glycerol-3-phosphate transporter & -2.54 \\
\hline$g l p X$ & gIpFKX & Fructose 1,6-bisphosphatase II & -1.51 \\
\hline $\operatorname{grxA} \mathrm{e}$ & & Glutaredoxin I & -2.19 \\
\hline $\operatorname{tr} x B^{b, e}$ & & Thioredoxin reductase, FAD/NAD(P)-binding & -1.88 \\
\hline $\operatorname{trx} C^{\mathrm{b}, \mathrm{e}}$ & & Thioredoxin 2 & -1.87 \\
\hline \multicolumn{4}{|l|}{ Protein fate } \\
\hline$c / 935^{f}$ & & Chaperone protein (F9 fimbriae) & -3.72 \\
\hline dnaK & dnaKJ & Molecular chaperone & -3.23 \\
\hline grpE & & Heat shock protein & -1.68 \\
\hline hscB & $h s c B A-f d x-i s c X$ & Co-chaperone with HscA & -1.81 \\
\hline hslO & & Hsp33-like chaperonin & -1.59 \\
\hline$h s / V$ & hsIVU & ATP-dependent protease peptidase subunit & -2.68 \\
\hline$h t p G^{\mathrm{b}}$ & & Heat shock protein 90 & -1.91 \\
\hline ibpA & $i b p A B$ & Heat shock chaperone & -2.63 \\
\hline $\operatorname{sip} A^{\mathrm{d}}$ & & $\begin{array}{l}\text { FKBP-type peptidyl-prolyl cis-trans isomerase } \\
\text { (rotamase) }\end{array}$ & -1.60 \\
\hline$y d h J$ & ydhIJK & Undecaprenyl pyrophosphate phosphatase & -2.05 \\
\hline \multicolumn{4}{|l|}{ Protein synthesis } \\
\hline $\operatorname{din} D$ & & DNA-damage-inducible protein & -1.90 \\
\hline lexA & lexA-dinF & Regulator for SOS regulon & -2.14 \\
\hline$n r d A$ & nrdAB & Ribonucleotide-diphosphate reductase alpha subunit & -1.58 \\
\hline recN & & DNA repair protein/recombination and repair protein & -2.80 \\
\hline$r p / R$ & $\begin{array}{l}\text { rpINXE-rpsNH-rpIFR-rpsE-rpmD- } \\
\text { rpIO-secY-rpmJ }\end{array}$ & $50 \mathrm{~S}$ ribosomal protein LI8 & -1.59 \\
\hline rp/W & $\begin{array}{l}\text { rpsj-rpICDWB-rpsS-rpIV-rpsC-rpIP- } \\
\text { rpmC-rpsQ }\end{array}$ & $50 S$ ribosomal protein $\mathrm{L} 23$ & -1.91 \\
\hline umuD & umuDC & DNA polymerase $V$, subunit $D$ & -1.72 \\
\hline \multicolumn{4}{|c|}{ Purines, pyrimidines, nucleosides and nucleotides } \\
\hline $\operatorname{carA} A^{b}$ & carAB & Carbamoyl-phosphate synthase small subunit & -2.02 \\
\hline guaB & guaBA & Inositol-5-monophosphate dehydrogenase & -2.33 \\
\hline purH & purHD & $\begin{array}{l}\text { Bifunctional phosphoribosylaminoimidazolecarboxamide } \\
\text { formyltransferase/IMP cyclohydrolase }\end{array}$ & -3.01 \\
\hline purl & & Phosphoribosylformyl-glycineamide synthetase & -3.33 \\
\hline purM & purMN & Phosphoribosylaminoimidazole synthetase & -2.62 \\
\hline pyrL & PyrLBI & Orotate phosphoribosyltransferase & -1.96 \\
\hline \multicolumn{4}{|l|}{ Cell envelope } \\
\hline bcsZ & bcsABZC & Endo-I,4-D-glucanase & -1.58 \\
\hline eptA & & Predicted metal dependent hydrolase & -1.68 \\
\hline$r f a j$ & rfaQGPSBIJYZ-waaU & Lipopolysaccharide I,2-glucosyltransferase & -1.68 \\
\hline rffC & $\begin{array}{l}\text { rfe-rffACDEGHMT-wzxE-wzyE- } \\
\text { wzzE }\end{array}$ & $\begin{array}{l}\text { Lipopolysaccharide biosynthesis protein/TDP- } \\
\text { fucosamine acetyltransferase }\end{array}$ & -1.66 \\
\hline yeiU & yeiRU & Undecaprenyl pyrophosphate phosphatase & -1.57 \\
\hline \multicolumn{4}{|c|}{ Fatty acid and phospholipid metabolism } \\
\hline$f a b B^{b}$ & & 3-oxoacyl-(acyl carrier protein) synthase & -1.51 \\
\hline yieE $E^{b}$ & yieEF & Predicted phosphopantetheinyl transférase & -1.53 \\
\hline \multicolumn{4}{|l|}{ Transcription } \\
\hline bas $R$ & basRS ${ }^{b}$ & $\begin{array}{l}\text { DNA-binding response regulator in two-component } \\
\text { regulatory system with BasS }\end{array}$ & -1.68 \\
\hline $\mathrm{crl}$ & & Curlin genes transcriptional activatory protein & -2.52 \\
\hline$f i m B$ & & $\begin{array}{l}\text { Type I fimbriae regulatory protein/Inversion of on/off } \\
\text { regulator of fimA }\end{array}$ & -1.66 \\
\hline
\end{tabular}


Table 2: Down-regulated genes in $\mathrm{K} 3$ strain (Continued)

\begin{tabular}{|c|c|c|c|}
\hline$p d h R^{b}$ & pdhR-aceEF-IpdA & $\begin{array}{l}\text { Transcriptional regulator for pyruvate dehydrogenase } \\
\text { complex }\end{array}$ & -3.42 \\
\hline$r p o D$ & $r p s U-d n a G-r p o D$ & RNA polymerase sigma factor & -1.65 \\
\hline \multicolumn{4}{|c|}{ Cellular processes } \\
\hline$c / 936^{f}$ & & Type I fimbrial protein (homologue) & -3.23 \\
\hline $\operatorname{fim} A^{c}$ & fimAICDFGH & Major type I subunit fimbrin (pilin) & -2.10 \\
\hline$y d e Q^{b}$ & & Predicted fimbrial-like adhesin protein (F9 fimbriae) & -1.57 \\
\hline$y$ deR & ydeRSTb & Hypothetical fimbrial-like protein (F9 fimbriae) & -2.21 \\
\hline \multicolumn{4}{|c|}{ Regulatory function } \\
\hline oxyse & & Global regulatory RNA & -1.82 \\
\hline \multicolumn{4}{|c|}{ Central intermediary metabolism } \\
\hline$i s c R$ & iscRSUA & NifU-like protein/Scaffold protein & -1.62 \\
\hline \multicolumn{4}{|c|}{ Unknown function } \\
\hline c3759b,f & parC-c3759 & Hypothetical protein & -1.72 \\
\hline pqiA & pqiAB & Paraquat-inducible membrane protein & -1.70 \\
\hline yhcN & & Unknown & -7.82 \\
\hline$y j b C$ & ybjC-nfsA-rimK-ybjN & Hypothetical protein & -1.54 \\
\hline$y b c U$ & & Bor protein homolog from lambdoid prophage DLPI2 & -1.62 \\
\hline$z 5852$ & & Hypothetical protein & -1.52 \\
\hline \multicolumn{4}{|c|}{ Biosynthesis of cofactors, prosthetic groups and carriers } \\
\hline thic & thiCEFSGH & Thiamine biosynthesis protein & -3.30 \\
\hline \multicolumn{4}{|c|}{ Mobile and extrachromosomal element functions } \\
\hline$h f q$ & yjeFE-amiB-mutL-miaA-hfq-hflXKC & RNA-binding protein & -1.56 \\
\hline$z 3347^{f}$ & & Unknown protein encoded within prophage CP-933V & -1.65 \\
\hline$z / 876^{f}$ & & Putative endolysin of prophage CP-933X & -1.85 \\
\hline
\end{tabular}

a The first down-regulated gene of the operon is shown, $b$ Indicates the presence of Pho box in the gene promoter, ${ }^{c}$ Genes belonging to RpoS regulon, ${ }^{d}$ Genes involved in acid stress response, e Genes involved in oxidative stress response, ${ }^{f}$ Pathogen-associated ORF, $\mathrm{g}$ Genes in bold are down-regulated in $\mathrm{K} 3$ strain.

the differentially expressed genes [20]. Ninety-one genes or transcriptional units possessed putative Pho box(es), including the known Pho regulon members (Tables 1 and 2). Differentially regulated genes such as those involved in amino acid acquisition ( $g \ln H P Q$, artJ and oppABC), energy metabolism (srlAEBD-gutM-srlR-gutQ, treA, talA, ulaABC$D E F$, ulaG and $g l p D$ ), acid resistance (gadA and gadBC) and F9 fimbriae biosynthesis ( $y d e T S R$ and $y d e Q$ ) possess putative Pho box(es). Distribution of putative Pho regulon members across different functional classes supports the hypothesis that the Pho regulon overlaps and interacts with several other control circuits [1]. However, further studies will be required to establish whether these genes are directly regulated by PhoB.

\section{Validation of microarray results by $q R T-P C R$}

Validation of microarray results was achieved using qRTPCR. Fifteen genes representing a wide range of gene expression ratios ( 5 up-, 8 down-regulated and 2 non-differentially expressed genes) in $\mathrm{K} 3$ strain were selected for comparative qRT-PCR analysis (Table 3). Comparison of gene expression by microarray hybridizations and qRT-PCR demonstrated a very high level of concordance between the datasets, which is represented by a correlation coefficient of 0.94 and a Pearson correlation of 0.97 (Fig. 2).

\section{Global stress response}

Globally, the transcriptional profile of strain K3 indicated that in addition to up-regulating genes associated with scavenging pathways for phosphate acquisition and conservation, the pst mutant also demonstrated changes in expression of genes dealing directly with global stress. Many lines of evidence suggest that the Pho regulon and the stress response are interrelated [1]. The gene expression profile of strain $\mathrm{K} 3$ represents an exacerbated response in which the strain reacts to an inaccurate detection of phosphate-limiting conditions when, in fact, phosphate levels are actually abundant. This adaptive response entails the induction of different mechanisms to optimize the acquisition and the bioavailability of phosphate and to maintain the essential biochemical reactions active. In addition, during growth, the $\mathrm{K} 3$ mutant activates a generalized stress response adaptation.

\section{Genes associated with the $R$ poS regulon}

The Pho regulon and the RpoS regulon are interrelated regulatory networks of the bacterial adaptive response [1]. RpoS is a sigma factor implicated in the cellular response to many stresses. It is also implicated in the stationary phase and the induction of genes in nutrient-limiting environments [27]. The rpoS gene is expressed under a variety of growth conditions, but regulation and RpoS production is largely dependent on post-transcriptional stability $[27,28]$. During exponential growth, in the K3 mutant, the rpos gene was not differentially expressed. However, the RpoS-regulatory gene iraP was induced 4.2fold. IraP encodes an anti-adaptor protein that enhances RpoS stability and accumulation by inhibiting its target- 


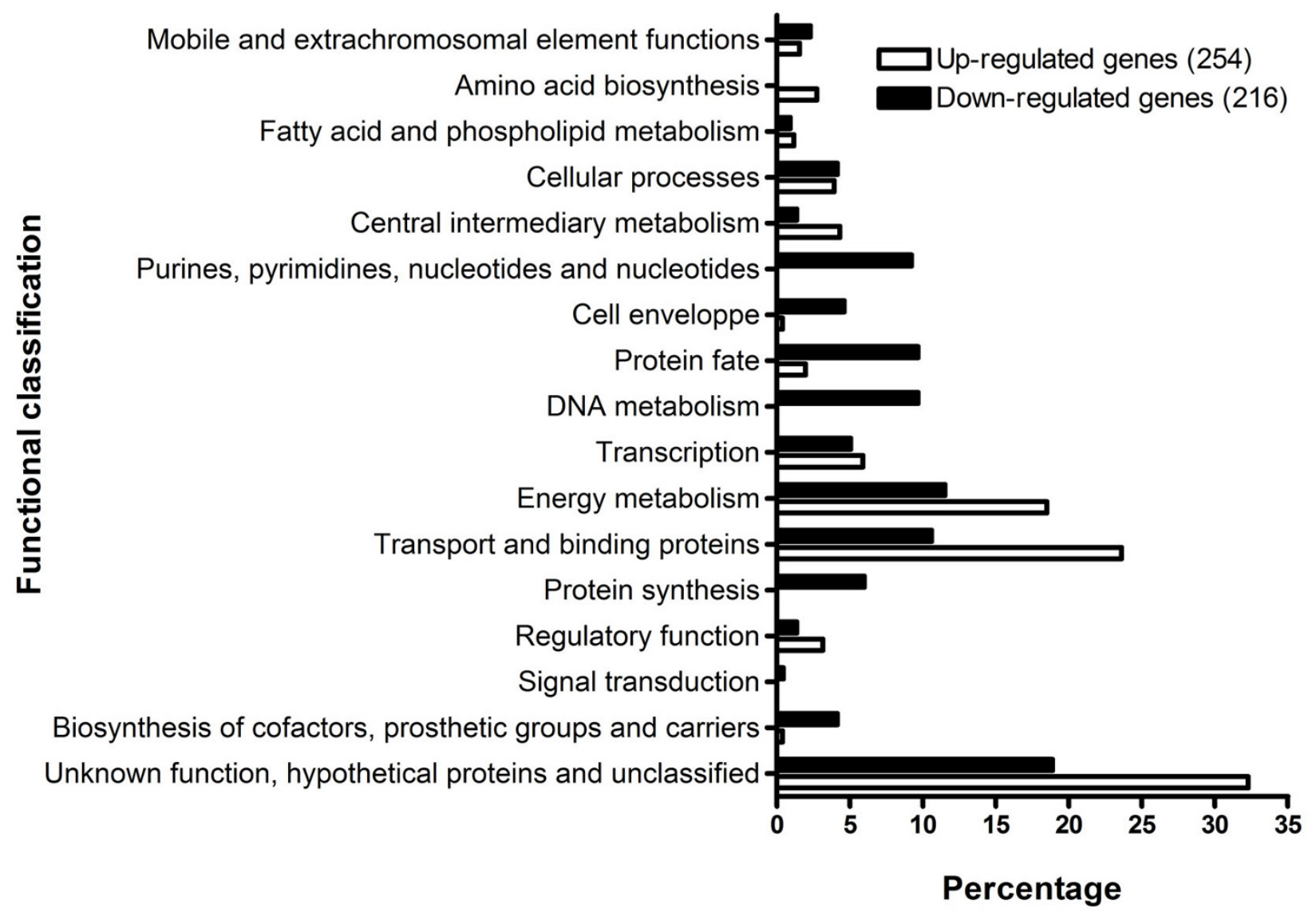

Figure I

Functional classification of the differentially expressed genes. White and black bars represent the up- and down-regulated genes, respectively. The $\mathrm{x}$-axis represents the percentage of the functional class according to the number of genes that were up- and down-regulated.

Table 3: Genes used for microarray validation with qRT-PCR

\begin{tabular}{lllll}
\hline No. & Gene & Gene title & Microarray Fold change (Log2) & qRT-PCR Fold change (Log2) \\
\hline I & phoA & Alkaline phosphatase & 6.816 & 7.600 \\
2 & gadW & DNA-binding transcriptional activator & 2.773 & 2.303 \\
3 & cdh & CDP-diacylglycerol phosphotidylhydrolase & 2.099 & 1.607 \\
4 & $y c g V$ & Predicted adhesin & 2.022 & 2.483 \\
5 & yddV & Diguanylate cyclase & 0.851 & 0.890 \\
6 & $y d e Q$ & Predicted fimbrial-like adhesin & -0.651 & -0.573 \\
7 & rpoD & RNA polymerase sigma factor & -0.640 & -1.087 \\
8 & $c r l$ & Curlin genes transcriptional activatory protein & -1.331 & -1.037 \\
9 & thiF & Thiamine biosynthesis protein & -2.152 & -1.787 \\
10 & $y h c N$ & Hypothetical protein & -2.967 & -5.680 \\
11 & lexA & Regulator for SOS regulon & -1.198 & -2.377 \\
12 & oxyS & Oxidative stress regulator & -0.864 & -1.777 \\
I3 & hfq & RNA-binding protein & -0.638 & -1.340 \\
14 & $y i d B$ & Hypothetical protein & -0.10 & -0.013 \\
15 & yeiR & Predicted enzyme & -0.04 & 0.212
\end{tabular}




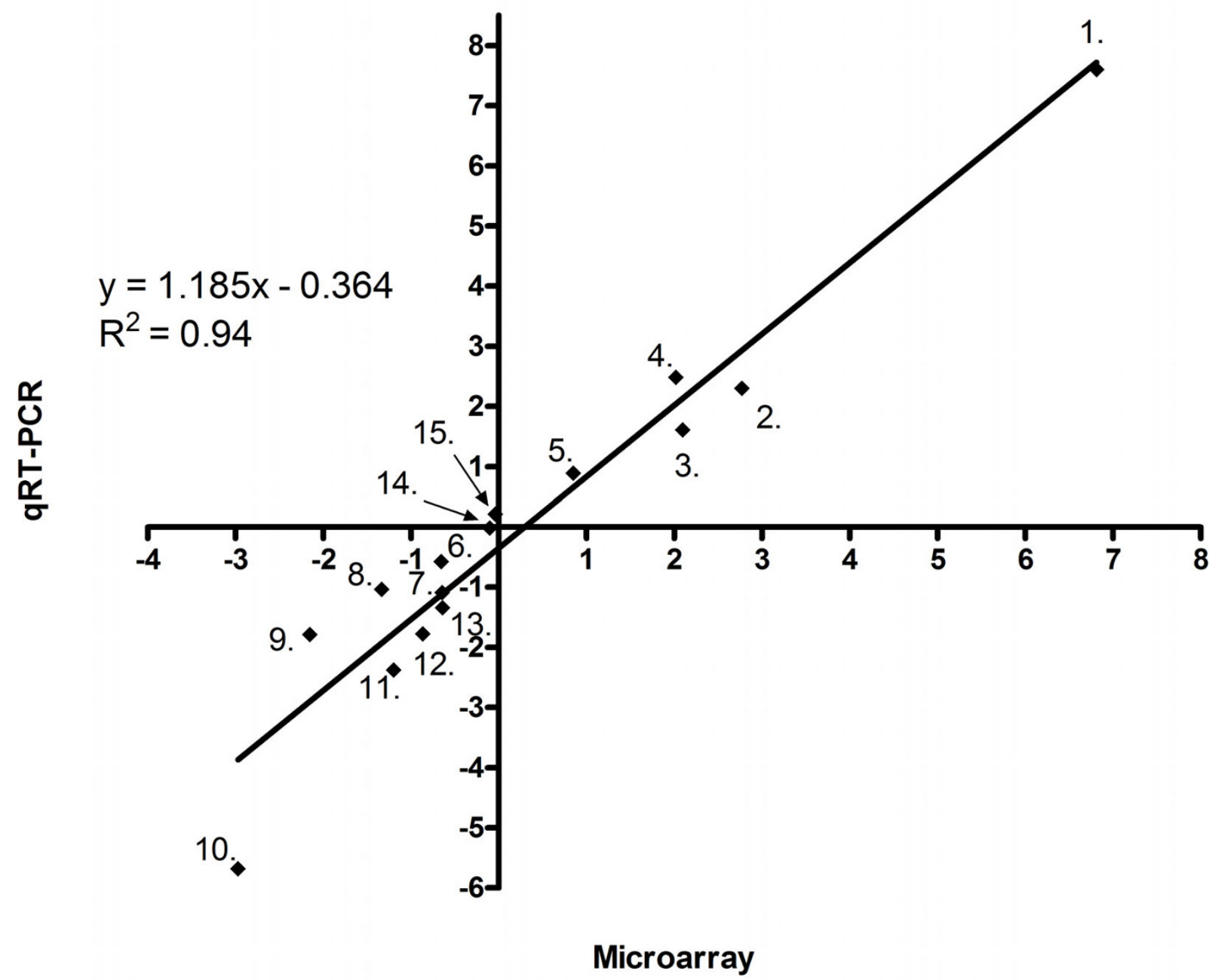

Figure 2

Microarray results validation by $\mathbf{q R T}-\mathbf{P C R}$. Five up-regulated genes, eight down-regulated genes and two non-differentially expressed genes are presented. Mean $\log _{2}$ ratios of the qRT-PCR experiments are plotted against the mean $\log _{2}$ ratios of the microarray experiments. Numbers on the graph refer to genes listed in Table 3 .

ing to the ClpXP degradosome [29,30]. Moreover, the small regulatory RNA (sRNA) OxyS, that inhibits the translation of rpoS, was down-regulated (-1.82-fold). Bougdour and Gottesman have recently shown that the transcription of the iraP gene is promoted by ppGpp accumulation during phosphate starvation [30,31]. These results suggest that in strain $\mathrm{K} 3$, during exponential phase, the sigma factor RpoS stability is increased, leading to regulatory expression of numerous RpoS-dependent genes. Accordingly, 49 genes known to be regulated by the RpoS sigma factor are differentially expressed in strain $\mathrm{K} 3$ (Tables 1 and 2). Hence, in the exponential growth phase, strain K3 may alter its gene regulation to respond to phosphate limitation, which includes establishment of a gen- eral stress response. Quantification of the RpoS protein would further demonstrate the establishment of the RpoS response, at mid-log phase of growth, in the pst $\mathrm{K} 3$ mutant.

\section{Oxidative stress response}

During aerobic growth, the cytotoxic by-products of the molecular oxygen metabolism, collectively known as reactive oxygen species (ROS), must be eliminated to reduce oxidative stress. It is generally thought that the primary endogenous source of ROS is the respiratory chain, namely the NADH dehydrogenase II, which can leak electrons to oxygen, thereby producing superoxide anion radicals $\left(\mathrm{O}_{2}^{-\bullet}\right)$. Superoxide is normally detoxified through 
the activities of superoxide dismutases and catalases that dismute $\mathrm{O}_{2} \bullet$ into molecular oxygen, hydrogen peroxide $\left(\mathrm{H}_{2} \mathrm{O}_{2}\right)$ and eventually to $\mathrm{H}_{2} \mathrm{O}$. However, if they are not rapidly detoxified, superoxide radicals can damage ironsulfur clusters in enzymes, thereby releasing $\mathrm{Fe}^{2+}$, which can react with $\mathrm{H}_{2} \mathrm{O}_{2}$ and produce reactive hydroxyl radicals $(\mathrm{HO} \bullet)$. $\mathrm{HO} \bullet$ can eventually initiate the oxidation of proteins, lipids and DNA [32]. Several genes that belong to the RpoS regulon are involved in defense against oxidative stress (katE, dps, sodC and $x t h A$ ) and/or OxyR (which controls oxyS, kat G, ahpCF, gorA, grxABC, dps and fur) and SoxR (which notably controls sodA, nfo and fur) (for a review, see reference [32]). In strain K3, some genes involved in the oxidative stress response were found to be differentially expressed. Among those, the dps (DNA protection protein and ferritin-like protein), sodC (superoxide dismutase $\mathrm{Cu}-\mathrm{Zn}$ ), grxB (Glutaredoxin 2), katE (catalase) and sufABCDSE (Fe-S cluster assembly proteins) genes were up-regulated from 1.95- to 1.75 -fold. The down-regulated genes (from -2.19- to -1.54-fold) were represented by grxA (glutaredoxin 1), $\operatorname{tr} x B$ (thioredoxin reductase), trxC (thioredoxin 2), pqiA (paraquatinducible protein) and $y b j C$ (predicted inner membrane protein). In addition, the sRNA OxyS regulator was downregulated (-1.82) in strain K3. OxyS has been proposed to play a role in protecting cells against the damaging effects of elevated hydrogen peroxide concentrations by controlling translation of $>40$ genes associated with the oxidative stress response $[30,33]$. Other, regulators involved in oxidative stress, such as OxyR and SoxRS, were not differentially expressed in strain $\mathrm{K} 3$.

Since expression of some genes whose products exhibit antioxidant activities is modulated, the viability to oxidative stress of $\mathrm{K} 3$ cells was tested using different reactive oxygen intermediate (ROI)-generating agents. We used $\mathrm{H}_{2} \mathrm{O}_{2}$ and various superoxide generators, such as plumbagin, phenazine methosulfate (PMS) and phenazine ethosulfate (PES) to evaluate the sensitivity of the K3 pst mutant and its wild-type parent strain $\chi 7122$. Strain K3 was more sensitive to oxidative stress than the parent strain $\chi 7122$, and wild-type resistance levels to all ROI compounds, except for $\mathrm{H}_{2} \mathrm{O}_{2}$, were restored by complementation (strain CK3) (Table 4). These results show that the pst mutation affects bacterial resistance to oxidative stress, and modulation of certain genes implicated in the oxidative stress response is not sufficient to confer resistance to this stress. Based on the transcriptional data, strain K3 may already be subjected to increased oxidative stress during growth, and is likely less able to cope with additional stresses incurred from exogenous ROI-generating compounds. Furthermore, Moreau et al. have shown that glucose metabolism in non-growing cells starved for $\mathrm{Pi}$ generates oxidative stress $[34,35]$. Since oxidative stress is increased during infection of the host, a decreased capac- ity to resist ROS could explain, at least in part, virulence attenuation observed for pst mutants $[4,5,7,36]$.

\section{Acid stress response}

The acid fitness island (AFI) contains genes encoding proteins that are known to provide protection against acid stress in E. coli. This broad acid response system helps the cell avoid self-imposed acid stresses that occur as a result of fermentation and enables the cell to survive to low $\mathrm{pH}$ conditions $[37,38]$. The microarray data demonstrate that the expression of the AFI genes increased significantly in strain K3. This includes the glutamate decarboxylase gene gadA (2.57-fold), the multiple transcriptional regulator genes that control expression of the glutamate dependent acid resistance (GDAR) system, gadE (3.60-fold), gadX (2.15-fold) and gadW (6.84-fold), the two chaperones hdeAB (2.10-fold for the hdeA gene), the multidrug resistance efflux transporter $m d t E$ (1.64-fold) and the transcriptional regulator $y h i F$ (1.66-fold). In accordance, the gadBC operon (4.91-fold for the gadB gene), which encodes the glutamate-decarboxylase and an antiporter, respectively, were also up-regulated. Regulation of the AFI and GDAR systems is extremely complex and multifactorial. The expression of these systems is controlled by a large number of regulators, including, among others, the EvgAS two-component system, the specific transcriptional regulators (GadX, GadW, YdeO, and GadE) and the RpoS sigma factor [39]. Up-regulation of genes involved in acid resistance suggests that the pst mutant may be subjected to increased acid stress during exponential growth. The effect of the Pho regulon on induction of the acid resistance response is likely to be indirect, since no putative Pho box(es) were found upstream of these regulators.

Previous reports have described the relationship between the Pho regulon and genes involved in acid stress resistance $[9,10,40,41]$. Transcriptional activation of the gadA/ $B C /$ E genes was observed in E. coli W3110 grown in low phosphate media $[9,10]$. In spite of the induction of acid

Table 4: Growth inhibition zone (mm) of APEC $\chi 7 \mid 22, K 3$ (pst mutant) and CK3 (complemented) strains to oxidative stress generating compounds ${ }^{a}$

\begin{tabular}{lllll}
\hline Strain & \multicolumn{5}{c}{ LB agar with: } \\
& Plumbagin $^{b}$ & $\mathbf{H}_{2} \mathbf{O}_{2}$ & PES & PMS \\
$\chi 7122$ & $8.5 \pm 0.1$ & $19.2 \pm 0.2$ & $15 \pm 0.4$ & $15.7 \pm 0.4$ \\
K3 & $10.7 \pm 0.6 c$ & $23.0 \pm 0.9$ & $19.2 \pm 0.5$ & $\mathbf{2 0 . 7} \pm \mathbf{0 . 2}$ \\
CK3 & $8.7 \pm 0.3$ & $\mathbf{2 1 . 9} \pm 1.0$ & $15.1 \pm 0.3$ & $16.7 \pm 0.2$ \\
\hline
\end{tabular}

${ }^{a}$ Data presented are the means \pm the standard deviations of six independent experiments.

b Compounds used were $10 \mu \mathrm{l}$ of plumbagin $(53 \mathrm{mM}), \mathrm{H}_{2} \mathrm{O}_{2}$ (30\% vol/ vol), phenazine ethosulfate (15 mM) (PES), or phenazine methosulfate (PMS) (I5 mM).

c Values indicated in bold text are significantly different $(P<0.05)$

compared to the mean of the wild-type strain. 
stress genes, strain K3 was previously shown to be more sensitive to acid stress [4]. It is possible that the pst mutant is already subjected to a decreased internal $\mathrm{pH}$ from an accumulation of organic acids produced by the glycolytic pathway, which could induce acid response genes during exponential growth [40]. As such, strain K3 which may already incur endogenous acid stress, may therefore be less able to cope when subjected to decreased external $\mathrm{pH}$ and acid stress, as observed by Lamarche et al. [4]. Based on these data, it would be interesting to compare the $\mathrm{pH}$ of the culture medium and the intracellular $\mathrm{pH}$ of the wild-type and pst mutant during growth, to assess whether induction of these acid response genes may be specifically due to increased acidity during growth.

\section{Transport and binding proteins}

In addition to Pho regulon members involved in the transport of phosphate and phosphorylated compounds, genes encoding amino acid and oligopeptide transport systems were up-regulated in strain K3. Indeed, the glutamine and the arginine transporters, encoded respectively by the glnHPQ operon and by the artIQM/artJ genes were up-regulated in strain K3 (1.57- and 1.74-fold, respectively). Down-regulation of the $\arg R$ (-1.57-fold) gene, which encodes the transcriptional repressor of the arginine transporter, occurred at the same time as with the up-regulation of the arginine transporter artIQM/artJ. The oligopeptide transporter, encoded by the oppABCDF genes, was also induced (2.66-fold). This transporter is specific for small peptides of up to five amino acids. Besides their roles in proteins synthesis, amino acids can serve as nitrogen, carbon and ATP sources and they can protect cells from different stresses, such as acid stress [42]. Furthermore, genes encoding the glutamine, arginine and oligopeptide transporters possess putative Pho box(es), which suggest that the uptake of oligopeptides and amino acids via these transporters may be directly regulated by the Pho regulon.

\section{Energy metabolism}

Some metabolic genes, involved in the catabolism of different carbon sources, were up-regulated. The srlAEBDgutM-srlR-gutQ operon, involved in glucitol transport and metabolism and belonging to the phosphoenolpyruvate (PEP): carbohydrate phosphotransferase system (PTS), was induced in strain K3 (4.61-fold) [43]. In addition, upregulation of genes enzymatically linked to the production of fructose-6-phosphate (talA and nagB) (1.57- and 1.8-fold, respectively) and glucose (melA and treA) (3.71and 1.67-fold, respectively), and metabolism of dihydroxyacetone (dhaKL) (1.85-fold) and L-ascorbate (ulaBDE and $u l a G$ ) (2.46-fold) were also induced. These catabolic pathways link to the glycolytic pathway, and intermediates could take part in the tricarboxylic acid cycle. Interestingly, the small regulatory RNA (sRNA)
SgrS, which inhibits synthesis of the PtsG glucose-specific PTS system and alleviates the effects of glucose-phosphate stress, was also up-regulated (1.98-fold), suggesting that the strain $\mathrm{K} 3$ has preferentially shifted to transport and metabolism of carbon sources other than glucose $[44,45]$.

On the other hand, repression of genes involved in catabolism of glycerol-3-phosphate (G3P) as a carbon source, such as the G3P transporter encoded by the glpTQ genes (2.54-fold) and the glycerol-3-dehydrogenase glpD (-3.56fold) was observed. The Glp system mediates utilization of G3P or its precursors, glycerol and glycerophosphodiesters. Since uptake of G3P by the GlpTQ transporter leads to $\mathrm{P}_{\mathrm{i}}$ counter flow and an overall loss of $\mathrm{P}_{\mathrm{i}}$ from the cell, it is not surprising that this system is repressed in strain K3 [46]. By contrast, genes encoding the other G3P-specific transporter Ugp were highly up-regulated (40.00-fold). Accordingly, the ugp genes are members of the Pho regulon. Under phosphate starvation conditions, G3P is transported by the Ugp transporter, which leads to the use of G3P as a phosphate source [2]. Identification of putative Pho box(es) upstream the $s r l$ and ula operons, the talA, tre $A$, and $u l a G$ genes denotes a possible direct connection between these catabolic pathways and the Pho regulon. Furthermore, the presence of putative Pho boxes upstream of the glpD gene suggests that the Pho regulon inhibits the use of G3P as carbon source. Thus, as the pst mutant falsely senses phosphate limitation, it may alter carbon uptake and utilization pathways in an effort to conserve phosphate sources. In order to specifically determine differences in carbon source utilization and transport by the pst mutant compared to its wild-type parent, strains could be compared for their capacity to metabolize and grow on different carbon sources.

\section{Protein fate and synthesis}

Many genes from the protein fate and synthesis functional classes were down-regulated in strain K3. These genes included those encoding components of the 30S and 50S ribosomal subunits and many chaperone genes involved in protein fate, such as those of the DnaK system and ironsulfur cluster assembly. The dnaKJ (-3.23-fold), grpE (1.68 -fold) and $i b p A B$ (-2.63-fold) genes comprise the DnaK system. This system is involved in many cytoplasmic events, such as folding of nascent polypeptide chains, rescue of misfolded proteins and assembly and disassembly of protein complexes $[47,48]$. Iron-sulfur cluster complexes play several important roles in cellular processes, such as iron storage, electron transfer and regulation of enzyme activity and gene expression [49]. However, genes involved in iron-sulfur cluster assembly were down-regulated in strain K3. They were represented by $h s c A B-f d x$ (1.81 -fold) and isc $U$ (-1.62-fold) genes. Repression of the DnaK system and iron-sulfur cluster assembly genes suggests a decrease in cellular processes occurring in strain 
K3. Down-regulation of chaperones and ribosomal components suggest a reduction in cellular processes and a potential increase of misfolded peptides, which could be deleterious for cells and may contribute, at least in part, to virulence attenuation of the APEC pst mutant strain. Such changes are likely to be indirectly influenced by the Pho regulon, since there were no putative Pho box(es) identified upstream of these genes.

\section{Cell membrane components}

In many bacteria, the Pho regulon was shown to be involved in regulation of some cell surface component modifications such as teichuronic acid, phosphate-free lipids, phospholipids and exopolysaccharides [1]. Among the differentially expressed genes in strain K3, 109 encode membrane components. Of these, 54 genes were up- and 55 were down-regulated (Tables 1 and 2, and additional files 2 and 3). Many of the up-regulated genes belong to the transport and binding protein functional class and include members of the Pho regulon that were increased by more than 15 -fold. In contrast, the proVWX operon (2.3 fold), involved in glycine betaine osmoprotector transport, demonstrated a decreased expression. This system is implicated in protection from osmotic shock [50]. Beside their role in energy metabolism, the talA (1.57fold) and treA (1.67-fold) genes were also induced by osmotic stress under aerobic conditions [51,52]. This suggests that the pst $\mathrm{K} 3$ strain was faced with osmotic stress, and down-regulation of the proVWX operon could reduce protection from this stress.

Among the down-regulated genes, 7 are involved in lipopolysaccharide (LPS) biosynthesis including lipid A modification. Indeed, the rffCDGH (-1.66-fold) and the $r f a J(-1.68$-fold) genes, respectively involved in the enterobacterial common antigen (ECA) biosynthesis pathway and LPS-core biosynthesis, were down-regulated. However, we previously did not observe any changes in O-antigen and/or ECA profiles by SDS-PAGE and Western blot analyses $[4,53]$. The results of this study suggest that subtle changes could indeed occur within the LPS structure in strain $\mathrm{K} 3$.

The eptA and yeiU genes, involved in lipid A modification, were also down-regulated (-1.68 and -1.57-fold, respectively). The eptA gene is the Salmonella pmrC ortholog and is involved in phosphoethanolamine $(\mathrm{pEtN})$ covalent modification of lipid A [54]. The BasRS two-component system that regulates eptA was also down-regulated (-1.68fold) in this study [54]. The basRS genes are orthologs of the pmrAB genes of Salmonella enterica, and PmrAB has been shown to be required for resistance to polymyxin $B$ and other antimicrobial compounds [55]. In addition, we have determined that, in strain $\mathrm{K} 3$, the down-regulation of yeiU (lpxT), encoding an undecaprenyl pyrophosphate phosphatase involved in the biosynthetic origin of the lipid A 1-pyrophosphate, correlated with a decrease in the hexa-acylated 1-pyrophosphate form of lipid A compared to the APEC strain $\chi 7122[53,56]$. Valvano MA and Raetz et al. have proposed that modification of lipid A might contribute to the fine-tuning of the lipopolysaccharide molecule, which is often the target of modifications that might provide adaptive advantages to changing environmental conditions $[57,58]$. LPS modification could contribute to the phenotypes observed in the pst mutant, such as decreased resistance to serum, acid and cationic antimicrobial peptides $[4,5,53]$. Furthermore, down-regulation of LPS modification genes may be a strategy used by the bacteria to optimize the $P_{i}$ availability. However, such cell surface modifications could play a role in the reduced virulence observed in pst mutants [1].

\section{Reduced expression of fimbrial genes and production of type I fimbriae}

Fimbriae are adhesive organelles of paramount importance for successful bacterial recognition and colonization of specific host tissues. Genes involved in type 1 and F9 fimbriae biosynthesis were down-regulated in the $\mathrm{K} 3$ strain (Table 2). Indeed, genes involved in the biosynthesis of type 1 (major type 1 subunit fimA, the chaperone fim $C$ and the fimI gene, whose function is not elucidated, and the regulator of type 1 fimbriae fimB $)(-2.1$ fold $)$ as well as F9 fimbriae (ydeTSR, ydeQ, c1936 and c1935) (3.72- to -1.54-fold) were repressed in strain K3. Type 1 and F9 fimbriae are important virulence factors involved in colonization and biofilm formation [59-63]. In APEC strains, type 1 fimbriae are preferentially expressed in air sacs, which are the primary infection site [64-66]. F9 fimbriae are homologous to type 1 fimbriae but are immunologically and functionally distinct [62]. However, the production of $\mathrm{F} 9$ fimbriae and the possible role of these fimbriae in APEC infections have not yet been investigated.

In order to investigate whether the decreased expression of fimbrial genes correlated with decreased fimbrial production, strain $\chi 7122$, the pst mutant K3 and the complemented mutant CK3 were grown under conditions used for microarray analyses and were examined by electron microscopy. Indeed, very few or no fimbriae were observed at the surface of cells of the $\mathrm{K} 3$ mutant, compared to wild-type strain $\chi 7122$ and the complemented strain CK3 (Fig. 3A,B,C). The type 1 fimbrial adhesin recognizes D-mannose receptors on cells, and mediates aggregation of yeast cells which are rich in mannose surface molecules [67].

When cultures of strains $\chi 7122$, the pst mutant K3, and the complemented CK3 were grown under conditions corresponding to those used in the microarray analyses, i.e. 
$\mathrm{OD}_{600} 0.6$, the $\mathrm{K} 3$ strain did not demonstrate any yeast aggregation even at the most concentrated bacterial cell suspension (approx. $1 \times 10^{11} \mathrm{cfu} / \mathrm{ml}$ ), whereas $\chi 7122$ and the complemented mutant CK3 agglutinated yeast at titers at least 10-fold less (approx. $1 \times 10^{10} \mathrm{cfu} / \mathrm{ml}$ ) (Fig 3D). When strains were cultured for $48 \mathrm{~h}$ without agitation, to enhance production of type 1 fimbriae, the K3 mutant agglutinated yeast cells, but 51-fold less than wild-type strain $\chi 7122$ and the complemented mutant (Fig. 3D). Hence, the pst mutant was shown to be considerably less able to produce type 1 fimbriae compared to its wild-type parent even under different growth conditions. To determine whether decreased yeast agglutination was specifically due to a reduction in production of the type 1 fimbrial adhesin, cell surface extracts were tested for production of the type 1 major fimbrial subunit, FimA, by Western blotting, and this confirmed an important reduction of FimA production in K3 strain, compared to $\chi 7122$ and CK3 strains (Fig. 3E).

Several studies have provided evidence that the expression of type 1 fimbriae is altered in response to environmental
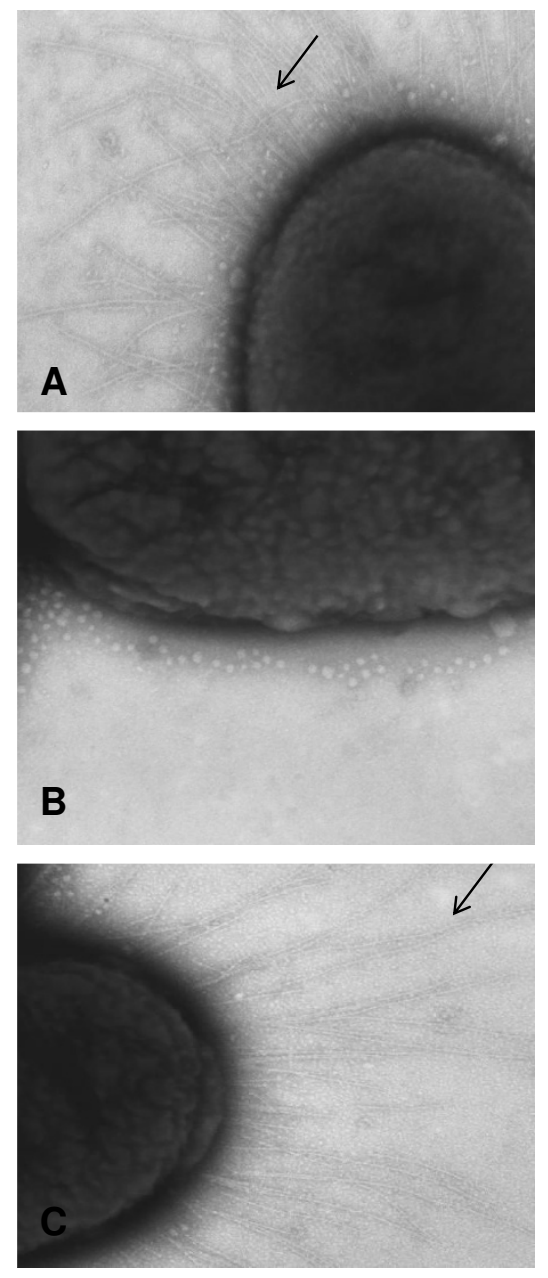

\section{Minimal bacterial titer allowing yeast agglutination}
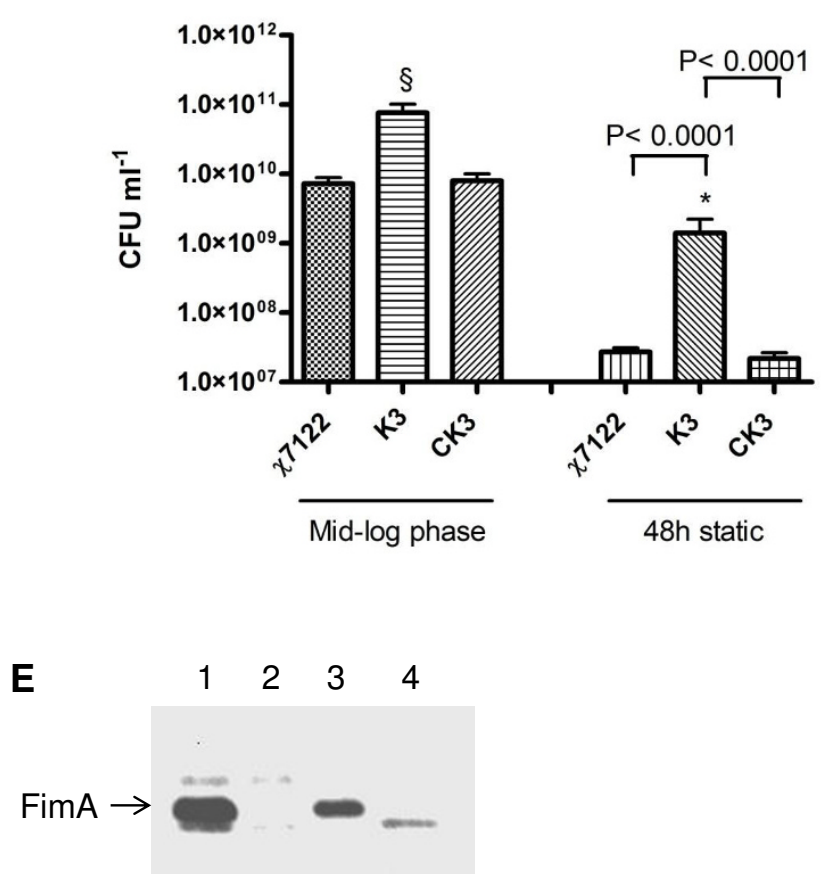

\section{Figure 3}

Production of type I fimbriae by the strain K3. A, B and C) Electron microscopy performed onto $\chi 7 \mathrm{I} 22$, K3 and CK3 strains, respectively, at $12000 \times$. Images show a typical field of view of bacteria and demonstrate that the K3 strain lacks fimbriae, compared to the $\chi 7122$ and CK3 strains. Arrow shows fimbriae on cell surface. D) Minimal bacterial titer allowing yeast agglutination. The $\chi 7122 \Delta$ fim $(\chi 7279)$ strain was used as negative control and did not show agglutination (data not shown). The $\S$ symbol shows that at mid-log phase of growth, no agglutination was observed at the highest cell titer for the K3 strain, which was also observed for $\Delta$ fim strain $\chi 7279$ (data not shown). Asterisks indicate significant differences observed between bacterial concentration of the wild-type $\chi 7 \mathrm{I} 22$ and the pst mutant strain K3 $(P$ value $=0.000 \mathrm{I})$ as calculated by Student's t test. No difference was observed between the $\chi 7 \mid 22$ and the CK3 strains. E) Western blot of protein extracts from strains $\chi 7 \mid 22$ (lane I), K3 (lane 2), CK3 (lane 3), and $\chi 7279$ (lane 4) using anti-FimA serum. 
stress conditions such as high osmolarity, $\mathrm{pH}$ and temperature, and that expression is induced upon entry into stationary phase $[68,69]$. Putative Pho box(es) were identified upstream of the $y d e T$ and $y d e Q$ genes, which are involved in F9 fimbriae biosynthesis, whereas no putative Pho box(es) were observed upstream of the genes involved in type 1 fimbriae biosynthesis. Taken together, results indicate that in the pst mutant, the production of type 1 fimbriae is repressed, and this loss of adhesin expression could be indirectly controlled by PhoBR. It was previously shown that in APEC strains, type 1 fimbriae are preferentially expressed in the air sacs and lungs, where the air sacs are the primary site of initial infection $[65,70]$. Thus, in the K3 strain, in addition to other previously established phenotypes, down-regulation of adhesins such as type 1 fimbriae could affect the initial step of colonization and possibly contribute to decreased virulence.

\section{Conclusion}

In conclusion, by assessing the global transcriptional response of a pst mutant, we determined that the effects of this mutation resulted in up-regulation of members of the Pho regulon, which are involved in phosphate uptake and metabolism. Transcriptional analyses also demonstrated the induction of a general stress response in the pst mutant, including genes involved in adaptation to acid stress, oxidative stress, and the general stress response (notably RpoS-regulated genes). Other changes included down-regulation of genes associated with cell surface composition. Phenotypic tests confirmed a reduced capacity of the pst mutant to produce type 1 fimbriae and a decreased capacity to resist oxidative stress. Altogether, our data provide further support that the Pho regulon is an important part of a complex network that encompasses not only phosphate homeostasis, but also adaptive responses to stress and altered regulation of a diversity of genes including virulence factors such as those encoding fimbrial adhesins.

\section{Abbreviations}

Pst system: Phosphate specific transport system; EDTA: ethylene diamine tetraacetic acid; cDNA: complementary DNA; ORF: Open Reading Frame; bp: base pair; $\mathrm{Fe}^{2+}$ : Ferrous iron; Fe-S: Iron-sulfur cluster; SDS-PAGE: Sodium Dodecyl Sulfate Polyacrylamide Gel Electrophoresis.

\section{Authors' contributions}

SC designed and performed the transcript profiling experiments, carried out downstream data analysis and drafted the manuscript. MGL constructed the K3 and CK3 strain, participated in the study design and revised the manuscript. PG executed the bioinformatics analysis and revised the manuscript. JS carried out the characterization of fimbriae experiments. JP performed the oxidative stress experiments. CMD supervised the characterization of fim- briae and oxidative stress experiments, performed data analysis and revised the manuscript. JH participated in the conception and supervised the design of the study, performed data analysis and revised the manuscript. All authors read and approved the final manuscript.

\section{Additional material}

\section{Additional file 1}

List of primers used in the qRT-PCR experiments. Complete lists of primers used in the qRT-PCR experiments, including primer sequences are shown.

Click here for file

[http://www.biomedcentral.com/content/supplementary/14712164-9-568-S1.doc]

\section{Additional file 2}

Up-regulated genes in the $\mathrm{K} 3$ strain. The complete list of genes up-regulated by at least 1.5-fold with a p-value of 0.05 and an estimated false discovery rate (FDR) of $2.71 \%$, in the pst $K 3$ strain. Probe number, gene name, fold change in Log2, and p-value were provided.

Click here for file

[http://www.biomedcentral.com/content/supplementary/14712164-9-568-S2.xls]

\section{Additional file 3}

Down-regulated genes in the $\mathrm{K} 3$ strain. The complete list of genes downregulated by at least 1.5-fold, with a p-value of 0.05 and an estimated false discovery rate (FDR) of $2.71 \%$, in the pst $K 3$ strain. Probe number, gene name, fold change in Log2, and p-value were provided.

Click here for file

[http://www.biomedcentral.com/content/supplementary/14712164-9-568-S3.xls]

\section{Acknowledgements}

We thank André Ponton, and Mathieu Miron, Génome Québec Innovation Centre (McGill University, Montreal, Canada), and Guillaume Bruant, Universite de Montréal for their help in the analysis of the microarray data. We are grateful to Turlough M. Finan and Rahat Zaheer, McMaster University, for sharing their data on E. coli genes with predicted PhoB boxes, and to Miria Elias from the NRC-Biotechnology Research Institute for technical assistance with the Agilent 2100 Bioanalyzer. We also thank Sébastien Houle, INRS-IAF, for his technical help with fimbrial extraction and electron microscopy experiments. We thank Daniel Dubreuil (Université de Montréal) for his critical reading of the manuscript.

This work was supported in part by grants to J.H. and C.M.D. from the Natural Sciences and Engineering Research Council of Canada (NSERC) and a Canada Research Chair to C.M.D.

\section{References}

I. Lamarche MG, Wanner BL, Crepin S, Harel J: The phosphate regulon and bacterial virulence: a regulatory network connecting phosphate homeostasis and pathogenesis. FEMS Microbiol Rev 2008, 32(3):46I-473.

2. Wanner BL: Phosphorus assimilation and control of the phosphate regulon. In Escherichia coli and Salmonella: cellular and molecular biology Volume I. Edited by: Neidhardt RCl, Ingraham JL, Lin EEC, Low KB, Magasanik B, Reznikoff WS, Riley M, Schaechter M, 
Umbrager HE. American Society for Microbiology, Washington, DC; 1996:1357-1381.

3. Ron EZ: Host specificity of septicemic Escherichia coli: human and avian pathogens. Curr Opin Microbiol 2006, 9(I):28-32.

4. Lamarche MG, Dozois CM, Daigle F, Caza M, Curtiss R 3rd, Dubreuil JD, Harel J: Inactivation of the Pst system reduces the virulence of an avian pathogenic Escherichia coli 078 strain. Infect Immun 2005, 73(7):4I38-4I45.

5. Daigle F, Fairbrother JM, Harel J: Identification of a mutation in the pst-phoU operon that reduces pathogenicity of an Escherichia coli strain causing septicemia in pigs. Infect Immun 1995, 63(I 2):4924-4927.

6. Dozois CM, Daigle F, Curtiss R 3rd: Identification of pathogenspecific and conserved genes expressed in vivo by an avian pathogenic Escherichia coli strain. Proc Natl Acad Sci USA 2003, I 00(I):247-252.

7. Bahrani-Mougeot FK, Buckles EL, Lockatell CV, Hebel JR, Johnson DE, Tang CM, Donnenberg MS: Type I fimbriae and extracellular polysaccharides are preeminent uropathogenic Escherichia coli virulence determinants in the murine urinary tract. Mol Microbiol 2002, 45(4): 1079-1093.

8. Khan MA, Isaacson RE: Identification of Escherichia coli genes that are specifically expressed in a murine model of septicemic infection. Infect Immun 2002, 70(7):3404-34I2.

9. Baek JH, Lee SY: Novel gene members in the Pho regulon of Escherichia coli. FEMS Microbiol Lett 2006, 264(I): 104-109.

10. Baek JH, Lee SY: Transcriptome analysis of phosphate starvation response in Escherichia coli. J Microbiol Biotechnol 2007 I 7(2):244-252.

II. VanBogelen RA, Olson ER, Wanner BL, Neidhardt FC: Global analysis of proteins synthesized during phosphorus restriction in Escherichia coli. J Bacteriol 1996, I78(I5):4344-4366.

12. Marc D, Arne P, Bree A, Dho-Moulin M: Colonization ability and pathogenic properties of a fim - mutant of an avian strain of Escherichia coli. Res Microbiol 1998, I49(7):473-485.

13. Provence DL, Curtiss R 3rd: Role of crl in avian pathogenic Escherichia coli: a knockout mutation of crl does not affect hemagglutination activity, fibronectin binding, or Curli production. Infect Immun 1992, 60(I I):4460-4467.

14. Bolstad BM, Irizarry RA, Astrand M, Speed TP: A comparison of normalization methods for high density oligonucleotide array data based on variance and bias. Bioinformatics 2003, I 9(2): 185-193.

15. Blazejczyk M, Miron M, Nadon R: FlexArray: A statistical data analysis software for gene expression microarrays. Genome Quebec, Montreal, Canada. Genome Quebec, Montreal, Canada 2007 [http://genomequebec.mcgill.ca/FlexArray/].

16. Irizarry RA, Bolstad BM, Collin F, Cope LM, Hobbs B, Speed TP. Summaries of Affymetrix GeneChip probe level data. Nucleic Acids Res 2003, 3 I (4): el 5.

17. Peterson JD, Umayam LA, Dickinson T, Hickey EK, White O: The Comprehensive Microbial Resource. Nucleic Acids Res 2001, 29(I): I23-I 25.

18. Livak KJ, Schmittgen TD: Analysis of relative gene expression data using real-time quantitative PCR and the 2(-Delta Delta C(T)) Method. Methods 200I, 25(4):402-408.

19. Blanco AG, Sola M, Gomis-Ruth FX, Coll M: Tandem DNA recognition by PhoB, a two-component signal transduction transcriptional activator. Structure 2002, I0(5):70I-7I3.

20. Yuan ZC, Zaheer R, Morton R, Finan TM: Genome prediction of PhoB regulated promoters in Sinorhizobium meliloti and twelve proteobacteria. Nucleic Acids Res 2006, 34(9):2686-2697.

21. Sabri M, Caza M, Proulx J, Lymberopoulos MH, Bree A, MoulinSchouleur M, Curtiss R 3rd, Dozois CM: Contribution of the Sit$A B C D, M n t H$, and FeoB metal transporters to the virulence of avian pathogenic Escherichia coli 078 strain chi7 I22. Infect Immun 2008, 76(2):60I-6II.

22. Lymberopoulos MH, Houle S, Daigle F, Leveille S, Bree A, MoulinSchouleur M, Johnson JR, Dozois CM: Characterization of Stg fimbriae from an avian pathogenic Escherichia coli 078:K80 strain and assessment of their contribution to colonization of the chicken respiratory tract. J Bacteriol 2006, I 88( I 8):6449-6459.

23. Laemmli UK: Cleavage of structural proteins during the assembly of the head of bacteriophage T4. Nature 1970, 227(5259):680-685.
24. Dozois CM, Pourbakhsh SA, Fairbrother JM: Expression of $\mathbf{P}$ and type I (FI) fimbriae in pathogenic Escherichia coli from poultry. Vet Microbiol 1995, 45(4):297-309.

25. Torriani A: Influence of inorganic phosphate in the formation of phosphatases by Escherichia coli. Biochim Biophys Acta 1960, 38:460-469.

26. Johnson TJ, Kariyawasam S, Wannemuehler Y, Mangiamele P, Johnson SJ, Doetkott C, Skyberg JA, Lynne AM, Johnson JR, Nolan LK: The genome sequence of avian pathogenic Escherichia coli strain OI:KI:H7 shares strong similarities with human extraintestinal pathogenic E. coli genomes. I Bacteriol 2007, 189(8):3228-3236.

27. Hengge-Aronis R: Signal transduction and regulatory mechanisms involved in control of the sigma(S) (RpoS) subunit of RNA polymerase. Microbiol Mol Biol Rev 2002, 66(3):373-395.

28. Loewen PC, Hu B, Strutinsky J, Sparling R: Regulation in the rpoS regulon of Escherichia coli. Can J Microbiol 1998, 44(8):707-717.

29. Bougdour A, Wickner S, Gottesman S: Modulating RssB activity: IraP, a novel regulator of sigma(S) stability in Escherichia coli. Genes Dev 2006, 20(7):884-897.

30. Altuvia S, Weinstein-Fischer D, Zhang A, Postow L, Storz G: A small, stable RNA induced by oxidative stress: role as a pleiotropic regulator and antimutator. Cell I997, 90(I):43-53.

31. Bougdour A, Gottesman S: ppGpp regulation of RpoS degradation via anti-adaptor protein IraP. Proc Natl Acad Sci USA 2007, I04(3I):|2896-90|.

32. Storz G, Imlay JA: Oxidative stress. Curr Opin Microbiol 1999 , 2(2): $\mid 88-194$.

33. Tjaden B, Goodwin SS, Opdyke JA, Guillier M, Fu DX, Gottesman S, Storz G: Target prediction for small, noncoding RNAs in bacteria. Nucleic Acids Res 2006, 34(9):279|-2802.

34. Moreau PL: Diversion of the metabolic flux from pyruvate dehydrogenase to pyruvate oxidase decreases oxidative stress during glucose metabolism in nongrowing Escherichia coli cells incubated under aerobic, phosphate starvation conditions. J Bacteriol 2004, I 86(2I):7364-7368.

35. Moreau PL, Gerard F, Lutz NW, Cozzone P: Non-growing Escherichia coli cells starved for glucose or phosphate use different mechanisms to survive oxidative stress. Mol Microbio 200I, 39(4): 1048-1060.

36. Buckles EL, Wang X, Lockatell CV, Johnson DE, Donnenberg MS: PhoU enhances the ability of extraintestinal pathogenic Escherichia coli strain CFT073 to colonize the murine urinary tract. Microbiology 2006, I52(Pt I): I53-160.

37. Hommais F, Krin E, Coppee JY, Lacroix C, Yeramian E, Danchin A Bertin P: GadE (YhiE): a novel activator involved in the response to acid environment in Escherichia coli. Microbiology 2004, I 50(Pt I):6I-72.

38. Mates AK, Sayed AK, Foster JW: Products of the Escherichia coli acid fitness island attenuate metabolite stress at extremely low $\mathrm{pH}$ and mediate a cell density-dependent acid resistance. J Bacteriol 2007, I89(7):2759-2768.

39. Foster JW: Escherichia coli acid resistance: tales of an amateur acidophile. Nat Rev Microbiol 2004, 2(I I):898-907.

40. Moreau PL: The lysine decarboxylase CadA protects Escherichia coli starved of phosphate against fermentation acids. J Bacteriol 2007, I89(6):2249-226I.

4I. Suziedeliene E, Suziedelis K, Garbenciute V, Normark S: The acidinducible asr gene in Escherichia coli: transcriptional control by the phoBR operon. J Bacteriol 1999, I8I(7):2084-2093.

42. Reitzer $\mathrm{L}$ : Catabolism of amino acids and related compounds. Escherichia coli and Salmonella: Cellular and Molecular Biology Online Version 2005 [http://www.ecosal.org]. Module 3.4.7.

43. Deutscher J Francke C, Postma PW: How phosphotransferase system-related protein phosphorylation regulates carbohydrate metabolism in bacteria. Microbiol Mol Biol Rev 2006, 70(4):939-1031.

44. Vanderpool CK: Physiological consequences of small RNAmediated regulation of glucose-phosphate stress. Curr Opin Microbiol 2007, I0(2):|46-|5|.

45. Vanderpool CK, Gottesman S: Involvement of a novel transcriptional activator and small RNA in post-transcriptional regulation of the glucose phosphoenolpyruvate phosphotransferase system. Mol Microbiol 2004, 54(4): 1076-1089. 
46. Boos W: Binding protein-dependent $\mathbf{A B C}$ transport system for glycerol 3-phosphate of Escherichia coli. Methods Enzymol 1998, 292:40-5I.

47. Bukau B, Horwich AL: The Hsp70 and Hsp60 chaperone machines. Cell 1998, 92(3):35I-366.

48. Mogk A, Deuerling E, Vorderwulbecke S, Vierling E, Bukau B: Small heat shock proteins, ClpB and the DnaK system form a functional triade in reversing protein aggregation. Mol Microbiol 2003, 50(2):585-595.

49. Johnson DC, Dean DR, Smith AD, Johnson MK: Structure, function, and formation of biological iron-sulfur clusters. Annu Rev Biochem 2005, 74:247-28I.

50. Barron A, Jung JU, Villarejo M: Purification and characterization of a glycine betaine binding protein from Escherichia coli. J Biol Chem 1987, 262(24): | |84|- | I846.

51. Boos W, Ehmann U, Bremer E, Middendorf A, Postma P: Trehalase of Escherichia coli. Mapping and cloning of its structural gene and identification of the enzyme as a periplasmic protein induced under high osmolarity growth conditions. J Biol Chem 1987, 262(27): |32 |2-132|8.

52. Weber A, Kogl SA, Jung K: Time-dependent proteome alterations under osmotic stress during aerobic and anaerobic growth in Escherichia coli. J Bacteriol 2006, I88(20):7165-7|75.

53. Lamarche MG, Kim SH, Crepin S, Mourez M, Bertrand N, Bishop RE, Dubreuil JD, Harel J: Modulation of hexa-acyl pyrophosphate lipid A population under Escherichia coli phosphate (Pho) regulon activation. J Bacteriol 2008, I 90(I 5):5256-5264.

54. Lee H, Hsu FF, Turk J, Groisman EA: The PmrA-regulated pmrC gene mediates phosphoethanolamine modification of lipid A and polymyxin resistance in Salmonella enterica. J Bacteriol 2004, I 86(I3):4|24-4I33

55. Nishino K, Hsu FF, Turk J, Cromie MJ, Wosten MM, Groisman EA: Identification of the lipopolysaccharide modifications controlled by the Salmonella PmrA/PmrB system mediating resistance to $\mathrm{Fe}$ (III) and $\mathrm{Al}(\mathrm{III})$. Mol Microbiol 2006, 6I(3):645-654.

56. Touze T, Tran AX, Hankins JV, Mengin-Lecreulx D, Trent MS: Periplasmic phosphorylation of lipid $A$ is linked to the synthesis of undecaprenyl phosphate. Mol Microbiol 2007, 67(2):264-277.

57. Raetz CR, Reynolds CM, Trent MS, Bishop RE: Lipid A modification systems in gram-negative bacteria. Annu Rev Biochem 2007. 76:295-329.

58. Valvano MA: Undecaprenyl phosphate recycling comes out of age. Mol Microbiol 2008, 67(2):232-235.

59. Dziva $F$, van Diemen PM, Stevens MP, Smith AJ, Wallis TS: Identification of Escherichia coli O 157: $\mathrm{H7}$ genes influencing colonization of the bovine gastrointestinal tract using signaturetagged mutagenesis. Microbiology 2004, I 50:363I-3645.

60. Kaper JB, Nataro JP, Mobley HL: Pathogenic Escherichia coli. Nat Rev Microbiol 2004, 2(2): 123-I 40.

61. Schembri MA, Klemm P: Biofilm formation in a hydrodynamic environment by novel fimh variants and ramifications for virulence. Infect Immun 200I, 69(3): I322-1328.

62. Ulett GC, Mabbett AN, Fung KC, Webb RI, Schembri MA: The role of F9 fimbriae of uropathogenic Escherichia coli in biofilm formation. Microbiology 2007, I 53:232I-233I.

63. van Diemen PM, Dziva F, Stevens MP, Wallis TS: Identification of enterohemorrhagic Escherichia coli O26: $\mathrm{H}$ - genes required for intestinal colonization in calves. Infect Immun 2005, 73(3): 1735-1743.

64. Dozois CM, Chanteloup N, Dho-Moulin M, Bree A, Desautels C, Fairbrother JM: Bacterial colonization and in vivo expression of $\mathrm{FI}$ (type I) fimbrial antigens in chickens experimentally infected with pathogenic Escherichia coli. Avian Dis 1994, 38(2):23I-239.

65. Pourbakhsh SA, Dho-Moulin M, Bree A, Desautels C, MartineauDoize $B$, Fairbrother JM: Localization of the in vivo expression of $P$ and $F I$ fimbriae in chickens experimentally inoculated with pathogenic Escherichia coli. Microb Pathog 1997, 22(6):33|-34I.

66. Barnes HJ, Vaillancourt J-P, Gross WB: Colibacillosis. In Diseases of poultry I Ith edition. Edited by: Saif YM, Barnes HJ, Glisson JR, Fadly AM, McDougald LR, Swayne DE. lowa State Press, Ames, lowa; 1997:631-652.

67. Mulvey MA: Adhesion and entry of uropathogenic Escherichia coli. Cell Microbiol 2002, 4(5):257-27I.
68. Gally DL, Bogan JA, Eisenstein BI, Blomfield IC: Environmental regulation of the fim switch controlling type I fimbrial phase variation in Escherichia coli K-12: effects of temperature and media. J Bacteriol |993, 175(19):6|86-6193.

69. Schwan WR, Lee JL, Lenard FA, Matthews BT, Beck MT: Osmolarity and $\mathrm{pH}$ growth conditions regulate fim gene transcription and type I pilus expression in uropathogenic Escherichia coli. Infect Immun 2002, 70(3): I 39I- 1402.

70. Gross WB: Colibacillosis. In Diseases of poultry Edited by: Calnek BW, Barnes HJ, Beard CW, Reid WM, Yoder HW Jr. Ames, IO: lowa State University Press; 2002:138-44.

Publish with Biomed Central and every scientist can read your work free of charge

"BioMed Central will be the most significant development for disseminating the results of biomedical research in our lifetime. "

Sir Paul Nurse, Cancer Research UK

Your research papers will be:

- available free of charge to the entire biomedical community

- peer reviewed and published immediately upon acceptance

- cited in PubMed and archived on PubMed Central

- yours - you keep the copyright 